\title{
Wywiad Chińskiej Republiki Ludowej - zarys struktur i metod działalności
}

China is different (Chiny sq̨ inne) Maksyma amerykańskich specjalistów zajmujących się kontrwywiadem ${ }^{1}$

\section{Wstęp}

Ctudia nad chińskim wywiadem przybliżają badaczy i ich czytelników $\checkmark$ do rozpoznania specyfiki sposobów osiągania celów przez to państwo na arenie międzynarodowej. Wywiad stanowi element głęboko wpisany w chińskie pojmowanie rywalizacji międzypaństwowej, a jego zasadniczy efekt pracy, czyli wiedza, jest dla decydentów kluczowym elementem racjonalnego procesu decyzyjnego w polityce zagranicznej i bezpieczeństwa. Działalność wywiadowcza jest również ważnym narzędziem umożliwiającym zmniejszenie luki technologicznej dzielącej ChRL od krajów Zachodu. Wieloletnie tradycje, wielkość i status międzynarodowy sprawiają, że służby wywiadowcze Chińskiej Republiki Ludowej mają pewne charakterystyczne elementy warunkujące specyfikę jego działania. Ich opis może przybliżyć zrozumienie filozofii leżącej u podstaw pracy wywiadowczej o chińskiej specyfice, roli tych instytucji w polityce zagranicznej oraz ich metodyki działania.

Autorzy postanowili skupić się na dwóch aspektach: strukturach odpowiedzialnych za wywiad oraz na specyfice podejścia do gromadzenia informacji. Główną przyczyną przyjęcia takiej perspektywy jest chęć nakreślenia głównych różnic w chińskiej pracy wywiadowczej w stosunku do państw zachodniego kręgu kulturowego, czy nawet Rosji. Spojrzenie

1 D. Stober, China is Different, http://www.pbs.org/wgbh/pages/frontline/shows/spy/ spies/different.html [dostęp: 10.10.2017]. 
na strukturę wywiadu i jej miejsce w systemie przybliża bowiem do zrozumienia, jaką rolę Chińczycy przypisują i czego oczekują od instytucji powołanych do zbierania informacji. Niewątpliwie istniejący model strukturalny jest powiązany z koncepcją pracy wywiadowczej. W tym aspekcie skupiono się na próbie wykazania, czym jest dla Chińczyków informacja wywiadowcza i przy użyciu jakich narzędzi należy ją pozyskiwać. Autorzy pragną jednak zaznaczyć, że zdecydowali się pominąć aspekt związany z wykorzystywaniem wywiadu do oddziaływania na inne państwa i społeczeństwa. W przypadku Chin jest to zagadnienie interesujące, ale z racji swojej obszerności zasługujące na omówienie w odrębnej publikacji.

\section{Chiński system wywiadowczy - zarys podmiotów i relacji}

W pełni wyczerpujący opis struktur wywiadowczych państwa jest każdorazowo, z uwagi na ich tajność, zadaniem trudnym, a często nawet niemożliwym. Przypadek Chińskiej Republiki Ludowej jest ponadto w dwójnasób szczególny. Według szacunków ośrodka analitycznego Stratfor ponad 70\% chińskich operacji wywiadowczych nie jest prowadzonych przez oficjalnie do tego predestynowane instytucje państwowe, ponieważ pozyskiwaniem informacji zajmuje się szeroki wachlarz podmiotów w postaci instytucji naukowych, agencji medialnych ${ }^{2}$, chińskich organizacji pozarządowych itd. Wykorzystywanie przez Pekin zróżnicowanych i niezwiązanych bezpośrednio z działalnością wywiadowczą instytucji nie powinno być zaskoczeniem, biorąc pod uwagę, że jest to powszechna praktyka na całym świecie. Analitycy Stratfor zwracają jednak uwagę, że tym, co wyróżnia model chiński, to fakt, że wyżej wspomniane „niewywiadowcze” instytucje nie tylko wspierają pracę cywilnego i wojskowego wywiadu, ale również działają niejako oddzielnie i ze sobą konkurują ${ }^{3}$. Kwestią, która dodatkowo utrudnia badanie tego zagadnienia, jest fakt, że Chińska Republika Ludowa wciąż jest państwem o ustroju na pograniczu autorytaryzmu i to-

2 Zob. działalność dziennikarzy agencji Xinhua (pol. „Nowe Chiny”) w trakcie wydarzeń w Polsce w październiku 1956 roku i ich rolę w dostarczaniu informacji odnośnie do sytuacji w naszym kraju: P. Madejczyk, Rok 1956: Chiny a polski Październik, https://www.swps.pl/nauka-i-badania/materialy-ccaw/2444-rok-1956-chiny-a-polski-pazdziernik [dostęp: 1.09.2017].

3 Intelligence Services, Part. 1: Espionage with Chinese Characteristics, s. 11, https:// wikileaks.org/gifiles/attach/133/133464_INTEL_SERVICES_CHINA.pdf [dostęp: 1.09.2017]. 
talitaryzmu ${ }^{4}$, co niewątpliwie rzutuje negatywnie na dostępność oraz wiarygodność źródeł i analiz o chińskiej proweniencji.

Podobnie jak w wielu innych państwach na świecie służby wywiadowcze w Chinach dzielą się na cywilne i wojskowe. W literaturze przedmiotu w kontekście instytucji cywilnych wymienia się przeważnie dwie - Ministerstwo Bezpieczeństwo Publicznego i Ministerstwo Bezpieczeństwa Państwowego ${ }^{5}$. Zadania Ministerstwa Bezpieczeństwa Publicznego obejmują jednak głównie obszar wewnętrzny kraju. Jest to instytucja o szerokim zakresie kompetencji, zajmuje się zarówno nadzorem służb policyjnych, jak i prowadzeniem działania z zakresu wywiadu wewnętrznego (ang. domestic intelligence) związane z inwigilacją dysydentów oraz obcokrajowców w Chinach. Działania Ministerstwa Bezpieczeństwa Publicznego w tym zakresie są koordynowane z Ministerstwem Bezpieczeństwa Państwowego ${ }^{6}$.

Ministerstwo Bezpieczeństwa Państwowego jest właściwą służbą w zakresie prowadzenia cywilnego wywiadu zagranicznego, w pewnym zakresie zajmującą się również rozpoznawaniem i monitorowaniem zagrożeń wewnętrznych. Instytucja ta powstała w wyniku przebudowy chińskiego aparatu bezpieczeństwa będącej elementem szerszych reform Deng Xiaopinga, które m.in. zredefiniowały dotychczasową koncepcję polityki zagranicznej ChRL w latach 80. ubiegłego wieku, a przed wszystkim pozwoliły wkroczyć Chinom na ścieżkę dynamicznego rozwoju gospodarczego $^{7}$. Deng Xiaoping, dwukrotnie represjonowany w czasie „rewolucji

4 Bezsprzecznie wszelkie próby klasyfikacji chińskiego ustroju politycznego muszą być obarczone wieloma zastrzeżeniami, gdyż podlega on ciągłej i żywiołowej ewolucji. Autorzy na chwilę obecną przyjmują, że współczesnym Chinom w wielu obszarach wciąż bliżej jednak do totalitaryzmu; zob. M. Adamczyk, Media we wspótczesnym państwie totalitarnym na przykładzie Chińskiej Republiki Ludowej, [w:] Media XXI wieku. Studia interdyscyplinarne, red. A. Momot, A. Drabina, Wrocław 2016, s. 12-16.

5 D. Pożaroszczyk, Wywiad Chińskiej Republiki Ludowej-Charakterystyka i zagrożenia dla Polski, „Przegląd Bezpieczeństwa Wewnętrznego” 2017, nr 16, s. 99; P. Becker, Eyes and ears of the dragon, s. 9, http://www.nisa-intelligence.nl/PDF-bestanden/NISAcongresBecker. pdf [dostęp: 1.09.2017].

6 Intelligence Services..., op.cit., s. 8.

7 Zob. więcej na temat reform: D. Dębicka, Reformy Deng Xiaopinga i ich wptyw na gospodarkę wspótczesnych Chin, „Pisma Humanistyczne” 2013, nr 9, s. 139-154; M. Kamil, Nieważne, jakiego koloru jest kot - ważne, by tapat myszy. Deng Xiaoping i droga komunistycznych Chin do kapitalizmu, „Ogrody Nauk i Sztuk” 2015, nr 5, s. 151-158; M. Żmuda, Przyczyny wejścia Chińskiej Republiki Ludowej na ścieżkę przyspieszonego wzrostu gospodarczego, [w:] Wybrane 
kulturalnej"8, nabrał przekonania, że jego kraj potrzebuje nowoczesnej, odpolitycznionej i niekoniecznie wzorowanej na radzieckim Komitiet gosudarstwiennoj biezopasnosti (KGB) służby specjalnej, która ostatecznie powstała w 1983 roku?.

W ciągu ostatnich 34 lat na czele Ministerstwa Bezpieczeństwa Państwowego stało 5 szefów $^{10}$, a instytucja stopniowo zwiększała swoje znaczenie w ramach polityki zagranicznej ChRL. Jej wpływ wzrósł w okresie szefowania Ministerstwu od 2007 do 2016 roku przez Geng Huichanga, uprzednio pełniącego funkcję szefa Chińskiego Instytutu Współczesnych Spraw Międzynarodowych (ang. CICIR, China Instututes of Contemporary International Relations). Przeszłość zawodowa Genga rzutowała na proces profesjonalizacji służb i traktowanie w sposób priorytetowy zadań z zakresu wywiadu zagranicznego. Istotne znaczenie miały również igrzyska olimpijskie w Pekinie w 2008 roku i zamieszki w prowincji Sinciang w $2009 \mathrm{roku}^{11}$. Obecnie w zakresie działania wywiadu zagranicznego do obszarów zainteresowania Ministerstwa zalicza się informacje o charakterze naukowo-technicznym, a także rozpoznanie oraz wywieranie wpływu na politykę wewnętrzną i zagraniczną krajów trzecich ${ }^{12}$. Na podstawie dostępnych informacji strukturę wewnętrzną Ministerstwa można ogólnie zarysować w sposób następujący ${ }^{13}$ :

problemy gospodarki światowej pierwszej dekady nowego wieku, red. W. Michalczyk, Wrocław 2009, s. 93-101; B. Góralczyk, Chiny piątej generacji, https://www.obserwatorfinansowy.pl/ tematyka/makroekonomia/chiny-piatej-generacji/ [dostęp: 1.09.2017].

8 Zob. D. Goodman, Deng Xiaoping and the Chinese Revolution: A Political Biography, Londyn-Nowy Jork 1994, s. 73-79; J.K. Fairbank, Historia Chin. Nowe spojrzenie, Warszawa-Gdańsk 2004, s. 375-376.

9 Decoding MSS: Ministry of State Security - China, http://www.asianwarrior. com/2016/09/decoding-mss-ministry-of-state-security-china.html [dostęp: 1.09.2017].

10 Byli to: Ling Yun (1983-1985), Jia Chunwang (1985-1998), Xu Yongyue (1998-2007), Geng Huichang (2007-2016), za: P. Mattis, Assessing the Foreign Policy Infuence of the Ministry of State Security, „China Brief” 2011, No. 11, s. 1-2. Od 2016 roku ministrem bezpieczeństwa państwowego ChRL jest Chen Wenqing; zob. Chen Wenqing, http://chinese-leaders.org/ chen-wenqing/ [dostęp: 1.09.2017]; P. Mattis, Chen Wenqing: China's New Man for State Security, http://nationalinterest.org/feature/chen-wenqing-china's-new-man-state-security-14153 [dostęp: 1.09.2017].

11 P. Mattis, Assessing the Foreign Policy..., op.cit., s. 1-2; L. Jakobson, D. Knox, New foreign policy actors in China, „SIPRI Policy Paper” 2016, No. 26, s. 22.

12 Intelligence Services..., op.cit., s. 7.

13 Ibidem, s. 5; P. Becker, op.cit., s. 9; MSS Organization, https://fas.org/irp/world/china/mss/org.htm [dostęp: 1.09.2017]; P. Monk, Chinese Spies and Our National Interest, http:// 
1. Biuro - biuro krajowe (werbunek i prowadzenie pozyskanych do współpracy obywateli Chin mających związki z zagranicą lub tam mieszkających).

2. Biuro - biuro zagraniczne (prowadzenie wywiadu strategicznego z pozycji dyplomatycznych oraz niedyplomatycznych).

3. Biuro - Hongkong/Makau/Tajwan (monitorowanie i pozyskiwanie informacji odnośnie do: aktywności organizacji, polityków i wojskowych z Tajwanu oraz innych państw w Hongkongu i Makau; pozyskiwanie dostępu do establishmentu politycznego w Hongkongu oraz monitorowanie tamtejszej sytuacji politycznej w wymiarze wewnętrznym i zagranicznym).

4. Biuro - wsparcie techniczne (zapewnienie rozwoju i bieżącego wsparcia techniki operacyjnej dla działań wywiadu i kontrwywiadu).

5. Biuro - wywiad wewnątrzkrajowy (nadzorowanie i koordynowanie pracy przedstawicielstw Ministerstwa na poziomie lokalnym).

6. Biuro - kontrwywiad (inwigilacja chińskich prodemokratycznych dysydentów za granicą przedstawicielstw dyplomatycznych oraz tych spośród zagranicznych instytucji, które w Chinach są uznawane za zagrożenie dla bezpieczeństwa wewnętrznego).

7. Biuro - oceny i analizy (przetwarzanie oraz dokonywanie ocen pozyskiwanych informacji i na ich podstawie przygotowywanie raportów dla kierownictwa państwa i partii).

8. Biuro - Instytut Współczesnych Stosunków Międzynarodowych (odrębna instytucja zajmująca się badaniem polityki i ekonomii globalnej oraz zgłębianiem problematyki poszczególnych państw i regionów świata).

9. Biuro - przeciwdziałanie inwigilacji (działania z zakresu kontrwywiadu zagranicznego: tropienie agentów zagranicznych służb specjalnych wśród personelu Ministerstwa, zabezpieczenie techniczne Ministerstwa i chińskich placówek zagranicznych, także ochrona kontrwywiadowcza chińskich studentów za granicą).

10. Biuro - wywiad naukowo-techniczny (pozyskiwanie informacji z zakresu ekonomii, nauki oraz technologii).

quadrant.org.au/magazine/2012/06/chinese-espionage-and-australia-s-national-interest/ [dostęp: 1.09.2017]. 
11. Biuro - wywiad komputerowy (analizowanie informacji pozyskanych przez sieci komputerowe, a także zabezpieczenie systemów informatycznych chińskich służb specjalnych przed atakiem w tej sferze).

12. Pozostałe: Biuro Łącznikowe, Departament Polityczny, Biuro Kadr i Szkoleń i podległy mu Uniwersytet Stosunków Międzynarodowych w Pekinie oraz szkoły językowe, biura administracyjne.

Chcąc omówić współczesne struktury wywiadu wojskowego Chińskiej Republiki Ludowej, należy poczynić zastrzeżenie, że od 2013 roku w Chińskiej Armii Ludowo-Wyzwoleńczej (ChALW) przeprowadzano zmiany organizacyjne, które prawdopodobnie pociągnęły za sobą pewne zmiany również w omawianym zakresie. Materiał źródłowy utrudnia jednak odtworzenie tych struktur we współczesnym kształcie, co skłoniło autorów do opisu sytuacji sprzed reformy ${ }^{14}$. Do 2013 roku do wywiadu wojskowego zaliczano przede wszystkim trzy jednostki organizacyjne Sztabu Generalnego (SG) ChALW:

- II Departament SG,

- III Departament SG,

- IV Departament SG .

Na czele Departamentu II stał dyrektor, któremu podlegało dwóch zastępców i komisarz polityczny, będący jednocześnie wysokiej rangi wojskowymi. Ocenia się, że polityczna zależność wywiadu wojskowego od Komunistycznej Partii Chin (KPCh) była mniejsza niż służb cywilnych - tak Ministerstwa Bezpieczeństwa Państwa, jak i Ministerstwa Bezpieczeństwa Publicznego ${ }^{15}$. Departament II określany był głównie jako wywiad osobowy

14 Na początku 2016 roku m.in. rozformowano Sztab Generalny ChALW i powołano w jego miejsce Połączone Sztaby. Trudno jednoznacznie powiedzieć, jakie zmiany wywołało to w strukturach odpowiedzialnych za wywiad wojskowy - niewątpliwie potrzeba czasu i dogłębnych badań, aby uzyskać chociażby szczątkowe informacje na ten temat. Wśród dokumentów i publikacji poruszających tę kwestię należy wymienić: 2016 Report to Congress, US-China Economic and Security Review Commission, Waszyngton 2016, s. 290; China's intelligence services and espionage operations, US-China Economic and Security Review Commission, Waszyngton 2016, s. 11; China reorients strategic military intelligence, http://www.janes.com/images/assets/484/68484/China_reorients_strategic_military_intelligence_edit.pdf [dostęp: 10.10.2017]; P. Mattis, Military Intelligence at a Crossroads, https://www.thecipherbrief.com/military-intelligence-at-a-crossroads [dostęp: 10.10.2017]; P. Mattis, E. Kania, Modernizing Military Intelligence: Playing Catchup (Part Two), https://jamestown.org/program/modernizing-military-intelligence-playing-catchup-part-two/ [dostęp: 10.10.2017].

15 A. Doval, Chinese Intelligence: From a party outfit to cyber warriors, New Delhi 2013, s. 11-12. 
(HUMINT) i zajmował się zarówno wywiadem strategicznym, jak i taktycznym $^{16}$. W obszarach jego zainteresowania były głównie takie zagadnienia dotyczące obcych sił zbrojnych, jak: ich Ordre de Bataille, doktryny i strategie, sposoby prowadzenia walki, uzbrojenie i wyposażenie, sylwetki dowódców, mocne i słabe strony, działalność kontrwywiadowcza. Departament II zajmował się także najprawdopodobniej tzw. płytkim wywiadem, czyli rozpoznaniem na obszarach przygranicznych ${ }^{17}$. Na podstawie analiz Stratforu oraz hinduskiego think thanku Vivekanada można zarysować strukturę wewnętrzną dotychczasowego Departamentu II w sposób następujący ${ }^{18}$ :

1. Biuro - wojkkowy wywiad osobowy (główne geograficzne obszary zainteresowania to Tajwan, Hongkong i Makau; ponadto koncentruje się ono na pozyskaniu technologii militarnych oraz kontrahentów skorych do zakupu sprzętu i uzbrojenia chińskiej proweniencji).

2. Biuro - wywiad taktyczny (koordynuje pracę wojskowych jednostek rozpoznawczych na terenach przygranicznych i szerzej oraz w oddziałach liniowych ChALW).

3. Biuro - nadzór nad attachatami wojskowymi.

4. Biuro - działalność wywiadowcza na obszarze: Federacji Rosyjskiej, byłych państw ZSRR i krajów Europy Zachodniej.

5. Biuro - odpowiedzialne za działalność łącznikową (oficjalnych przedstawicieli służby w innych państwach).

6. Biuro - prowadzenie wywiadu w krajach sąsiadujących z ChRL.

7. Biuro - wsparcie techniczne (m.in. koordynowanie podległych sił i środków w prowadzeniu wywiadu cybernetycznego).

8. Pozostałe: Biuro Kontroli Armii, Rozpoznanie Kosmiczne, Instytut Stosunków Międzynarodowych ChALW w Nankinie.

Kolejna struktura, Departament III, odpowiadała za wywiad sygnałowy (SIGINT) i bywała określana „chińskim NSA”19. Służba jest zaliczana do jednej z trzech największych tego typu na świecie ${ }^{20}$. Do jej zadań należały rozpoznanie i penetracja systemów informatycznych obcych misji dyplo-

\footnotetext{
162016 Report to Congress..., op.cit., s. 290.

17 Intelligence Services..., op.cit., s. 9.

18 Ibidem, s. 9-11; A. Doval, op.cit., s. 11-13.

192016 Report to Congress..., op.cit., s. 290.

20 A. Doval, op.cit., s. 13-14.
} 
matycznych, podmiotów gospodarczych, sił zbrojnych, placówek naukowych oraz oddziaływania psychologicznego, przechwytywanie komunikacji radiowej, kablowej oraz satelitarnej czy kryptografia i prowadzenie analiz wywiadowczych. Departament III dzielił się na 12 wydziałów operacyjnych zlokalizowanych w całym kraju, w skład których wchodzi od 6 do 14 mniejszych jednostek organizacyjnych. Na podstawie dostępnych źródeł autorzy przedstawiają następujące jednostki liniowe i funkcyjne ${ }^{21}$ :

1. Biuro - dekryptaż, szyfrowanie i inne zadania z zakresu bezpieczeństwa informacji.

2. Biuro - rejon zainteresowania: Stany Zjednoczone i Kanada.

3. Biuro - wywiad komunikacyjny (SIGINT) za pośrednictwem stacji nasłuchowych.

4. Biuro - rejon zainteresowania: Japonia i Korea.

5. Biuro - rejon zainteresowania: Rosja.

6. Biuro - Komisariat Polityczny.

7. Biuro - zadania niejasne (działalność biura jest prawdopodobnie związana z obroną oraz atakami na sieci komputerowe. Biuro współpracuje z szeregiem podmiotów zaangażowanych w prowadzenie działań wywiadowczych w cyberprzestrzeni).

8. Biuro - rejon zainteresowania: Zachodnia i Wschodnia Europa oraz prawdopodobnie reszta świata (Bliski Wschód, Afryka, Ameryka Łacińska).

9. Biuro - analizy strategiczne i zarządzanie bazą danych.

10. Biuro - zadania niejasne (prawdopodobnie ukierunkowane na Azję Centralną i Rosję oraz skupione na telemetrii i namierzaniu pocisków balistycznych).

12. Biuro - rejon zainteresowania: Rosja (szczegóły w zakresie różnic działalności z 5. Biurem nie są znane).

Departament IV Sztabu Generalnego Chińskiej Armii Ludowo-Wyzwoleńczej był natomiast odpowiedzialny za walkę elektroniczną (ELINT), ale też prowadzenie wywiadu elektronicznego oraz elektronicznych środków wsparcia (ESM - ang. Electronic Support Measures) ${ }^{22}$. Poza Depar-

21 M.A. Stokes, J. Lin, L.C. Russel Hsiao, The Chinese People's Liberation Army Signals Intelligence and Cyber Reconnaissance Infrastructure, s. 7-10, https://project2049.net/documents/pla_third_department_sigint_cyber_stokes_lin_hsiao.pdf [dostęp: 1.09.2017].

22 A. Doval, op.cit., s. 13-14. 
tamentami III i IV SG działalność wywiadowczą i rozpoznawczą podejmowały również jednostki organizacyjne różnych rodzajów sił zbrojnych (wojsk lądowych, rakietowych, lotniczych, marynarki wojennej) ${ }^{23}$.

Warto zaznaczyć, że wybrane struktury Departamentów III i IV odpowiadają za działania w cyberprzestrzeni, których znaczna część ma charakter ofensywny ${ }^{24}$ - większość zadań w tym zakresie spoczywa jednak na Departamencie III. Wskazuje się przy tym, że (podobnie jak w przypadku wywiadu osobowego) zadania te są znacząco zdecentralizowane, a wiele informacji jest pozyskiwanych przez mniej lub bardziej niezależne grupy hakerskie ${ }^{25}$. Należy przy tym pamiętać, że chiński wywiad w cyberprzestrzeni należy do jednego z najbardziej rozwiniętych na świecie. Ocenia się, że operacje w cyberprzestrzeni mają przede wszystkim na celu ${ }^{26}$ :

- wzmocnienie politycznej i gospodarczej kontroli w ChRL, w szczególności w zakresie zwalczania obcej propagandy oraz rozpoznania aktywności w sieci podejmowanych przez dysydentów;

- pozyskiwanie informacji ekonomicznych, technologicznych, politycznych i wojskowych za granicą.

Jak już wspomniano, w Chinach wiele instytucji zajmuje się pozyskiwaniem informacji wywiadowczych. W tym kontekście wymienia się agencję prasową Xinhua, wiele wojskowych i cywilnych instytutów oraz placówek naukowo-badawczych, placówki kulturalno-oświatowe oraz podmioty komercyjne. W zależności od profilu swojej działalności zarówno gromadzą informacje (głównie ze źródeł otwartych, ale również przez źródła osobowe - dziennikarzy, naukowców, biznesmenów itd.) i je przetwarzają, jak i są wykorzystywane jako miejsca przykrycia dla funkcjonariuszy wywiadu, rozprzestrzeniania sieci kontaktów czy kształtowania pozytywnego wizerunku Chin. Taki stan rzeczy ma istotne implikacje dla kształtu chińskiego systemu wywiadowczego. Ogromny strumień gromadzonych

232016 Report to Congress..., op.cit., s. 290.

24 W chińskiej doktrynie działań w cyberprzestrzeni funkcjonuje pojęcie „aktywnej obrony", której defensywny wydźwięk może okazać się mylący, ponieważ określa działania wywiadowcze mające na celu uzyskanie jak największej liczby informacji, w tym również dotyczących zagrożeń sieciowych; P. Borkowski, Koncepcja cyberbezpieczeństwa w ujęciu Chińskiej Republiki Ludowej - wybrane aspekty, „Przegląd Bezpieczeństwa Wewnętrznego” 2015, nr 13, s. 50;

25 Ibidiem, s. 54; T. Feakin, Enter the Cyber Dragon. Understanding Chinese intelligence agencies's cyber capabilities „Special Report” 2013, No. 50, s. 4.

26 T. Feakin, op.cit., s. 5. 
danych wymaga bowiem rozbudowanego zaplecza analitycznego, które umożliwi przeprowadzenie ich odpowiedniej oceny, przetworzenia, wyciągnięcia wniosków oraz przedstawienia w przystępnej dla decydentów formie. Jednak według niektórych autorów tak jak rozproszone są struktury odpowiedzialne za pozyskiwanie informacji, tak podobnie zdecentralizowane i często nieskoordynowane są instytucje odpowiedzialne za ich analizę $^{27}$. W związku z tym nie jest jasne, na ile wydolny jest chiński system wywiadowczy. Zdaniem Stratfor jego rozbudowana i niejasna struktura może przyczynić się do braku koordynacji pracy operacyjnej i analitycznej, a w konsekwencji - ograniczać możliwości całego systemu ${ }^{28}$.

\section{Oryginalna specyfika działalności}

Znaczne rozczłonkowanie i w gruncie rzeczy rozmycie struktur odpowiedzialnych za prowadzenie pracy wywiadowczej w ChRL ma źródło w specyficznym podejściu do tego obszaru działań. Chińską specyfikę wywiadu określa się często takimi określeniami, jak: „metoda mozaikowa”, „metoda tysiąca ziaren piasku” czy „metoda ludzkiej fali”29. Ich istotę objaśnia funkcjonująca wśród analityków zajmujących się chińskim wywiadem metafora, według której pewne państwo (np. Rosja), chcąc zbadać plażę, wysyła tam łódź podwodną, której załoga pod osłoną nocy pobiera próbki piasku w celu dokonania analizy. Metoda, którą zastosowaliby Chińczycy, to wysłanie tysiąca turystów, z których każdy zabrałby z plaży jedno ziarno piasku, a ponadto kiedy powróciliby do kraju, zostaliby poproszeni o otrzepanie ręczników z pozostałości plaży ${ }^{30}$.

Innymi słowy, jest to przejaw totalnego podejścia Chińczyków do działalności wywiadowczej. Zgodnie z takim założeniem każda informacja może być wartościowa, co sprawia, że jako zasadne postrzega się wykorzystanie w celu jej pozyskania maksimum posiadanych sił i środków (osobowych,

27 Ibidiem, s. 2. Sieć instytucji analitycznych biorących udział w chińskim cyklu wywiadowczym przedstawia jeden z raportów Rand Corporation z 1998 roku - M.D. Swaine, The role of Chinese military in national security policymaking. Revised edition, Rand National Defence Research Institute, Waszyngton 1998, s. 57-71.

28 Intelligence Services..., op.cit., s. 11.

29 China's intelligence services..., op.cit., s. 28; T. Feakin, op.cit., s. 8.

30 P. Monk, op.cit. 
technicznych, instytucjonalnych itd.). Przyjmując zatem w uproszczeniu o ile koncepcja służb zachodnich czy rosyjskich zakłada pozyskanie możliwie najbardziej wartościowych informacji niejawnych, o tyle chińskie podejście zakłada korzystanie z większej ilości i bardziej rozproszonych źródeł za cenę jakości dostarczanych przez nich danych. W takim ujęciu prawie każdy Chińczyk może okazać się przydatny dla wywiadu i w konsekwencji chińska diaspora stanowi jeden z jego fundamentalnych instrumentów. Dariusz Pożaroszczyk zwraca uwagę, że wynika to z dwóch zasadniczych elementów - dużej liczby emigrantów za granicą oraz ich odrębności kulturowej i etnicznej od reszty otaczających ich mieszkańców ${ }^{31}$. Społeczność ta, wykonując za granicą różne funkcje społeczne i czy zawodowe (studenci, stażyści, pracownicy firm technologicznych, przedsiębiorcy, naukowcy), może bowiem przynosić wiele pożytku. Pozyskiwanie informacji może polegać chociażby na dostarczaniu łatwo dostępnego sprzętu i technologii oraz różnych innych, pozornie mało wartościowych informacji ${ }^{32}$, a jednocześnie często działalność taka nie stanowi naruszenia prawa lub jest niezwykle trudna do wykrycia $^{33}$. Chińska diaspora daje również możliwości w zakresie pozyskiwania funduszy na rzecz wywiadu przez tworzenie zagranicznych przedsiębiorstw czy udział w programach grantowych. Wszystko to odpowiednio wykorzystane może zapewnić szeroki wachlarz możliwości dla pracy wywiadowczej. Należy przy tym zwrócić uwagę, iż chińskie władze starają się kontrolować emigrantów, a wyjazd za granicę często jest uzależniony od deklaracji współpracy z instytucjami państwowymi. To z kolei ułatwia werbunek, który może opierać się na motywach patriotycznych czy mniej lub

31 D. Pożaroszczyk, op.cit., s. 101.

32 Stratfor podaje, że często zdarza się, iż instytucje wywiadowcze po prostu zlecają etnicznym Chińczykom pozyskanie wybranych technologii podczas podróży, ale też wykorzystuje się kanały komercyjne, np. przez zakup sprzętu przez chińskie firmy lub działające pod przykrywką (np. w Hongkongu). Podobnie kwestia wygląda w innych sektorach: naukowym, gospodarczym itd. - Intelligence Services..., op.cit., s. 6.

33 T. Van Magers, funkcjonariusz FBI z długoletnim doświadczeniem w pracy w wydziale kontrwywiadu zajmującym się tematyką chińską, zwraca uwagę, że praca służb wywiadowczych Państwa Środka znacząco różni się od innych służb, np. rosyjskich. W omawianym przypadku zidentyfikowanie działalności szpiegowskiej jest bowiem jeszcze trudniejsze niż zwykle, i to nie tylko w zakresie dostarczenia materiału dowodowego w celu przygotowania aktu oskarżenia, ale również w zakresie rozpoznania kontrwywiadowczego (np. ustalenia służby, dla której pracują, jakich informacji poszukują itd.). Szerzej na ten temat zob. Intervwiew. T. Van Magers, http://www.pbs.org/wgbh/pages/frontline/shows/spy/interviews/vanmagers.html [dostęp: 13.10.2017]. 
bardziej zawoalowanym szantażu (np. w stosunku do rodziny, która mieszka Chinach). Bardzo często ma również motyw finansowy związany z ułatwieniem prowadzenia działalności gospodarczej ${ }^{34}$.

W'śród prób charakterystyki wywiadu chińskiego dominuje więc przekonanie, że opiera się on głównie na etnicznych Chińczykach jako źródłach informacji i polega częściej na nieprzeszkolonych źródłach osobowych, które pozyskują wiele informacji o niewielkiej lub ograniczonej wartości niż kadrowych oficerach wywiadu. Przy takim założeniu wywiad chiński jawi się jako przedsięwzięcie szeroko zakrojone, ale stosunkowo płytkie ${ }^{35}$. Nie wszyscy jednak uznają, że taki pogląd odpowiada rzeczywistości ${ }^{36}$. Wywiad o takim dorobku jak wywiad chiński, pomimo ograniczeń wynikających z różnic kulturowych i etnicznych, w oczywisty sposób musiał wykształcić narzędzia umożliwiające docieranie do bardziej wartościowych informacji. Wydaje się więc, iż musi funkcjonować kategoria bardziej wartościowej agentury, która przechodzi odpowiednie przeszkolenie, a do jej zadań należy gromadzenie wybranych informacji, werbunek źródeł osobowych, czasem także wpływ na politykę wewnętrzną oraz dezinformację w kraju działania. Ich bezpośrednie związki z ojczyzną występują rzadziej niż w przypadkach omówionych powyżej lub są skrzętnie ukrywane. Ryzyko dekonspiracji ma również obniżyć zakaz kontaktowania się z chińskimi placówkami dyplomatycznymi w państwie, w którym funkcjonują ${ }^{37}$.

Chiński wywiad jak każdy pozyskuje do współpracy także obcokrajowców, a jego funkcjonariusze służą w różnych miejscach przykrycia, zarówno legalnych (misje dyplomatyczne), jak i nielegalnych (dziennikarze, naukowcy, przedsiębiorcy itd.). W celu pozyskania źródła do współ-

\footnotetext{
34 Decoding MSS..., op.cit.; D. Pożaroszczyk, op.cit., s. 101.

35 P. Brookes, Legion of Amateurs: How China Spies, http://www.heritage.org/commentary/legion-amateurs-how-china-spies [dostęp: 13.10.2017].

36 Peter Mattis uważa, że taki pogląd jest zbyt ogólny i uproszczony, co sprawia, że skuteczne zapobieganie zjawisku chińskiego szpiegostwa staje się jeszcze trudniejsze. W ocenie autora nadmierne skupianie się na rozpoznaniu zagrożeń płynących z szeroko zakrojonej działalności wywiadowczej (metoda „tysiąca ziaren piasku”) przeciąża możliwości analityczne kontrwywiadu i odsuwa od sprawy najbardziej istotnej, a więc aktywności profesjonalnych instytucji wywiadowczych. Więcej na ten temat zob. P. Mattis, The Analytic Challenge of Understanding Chinese Intelligence Services, „Studies in Intelligence” 2012, No. 3 (56), s. 48-50; China's intelligence..., op.cit., s. 28-30.

37 Intelligence Sevices..., op.cit., s. 6; A. Książczak, Chińskie służby specjalne XXI wieku organizacja, metody i formy działania, „Forum” 2015, nr 2, s. 36-37.
} 
pracy wykorzystuje się znane i powszechnie stosowane metody: szantaż, korzyści finansowe, seks (tzw. honey trap) ${ }^{38}$, ale tym, co odróżnia metody pracy ze źródłami osobowymi w chińskim wykonaniu jest przede wszystkim dbanie o osobisty i przyjacielski wymiar relacji oraz zachowawczość w ujawnianiu swojej prawdziwej afiliacji ${ }^{39}$.

Chiński wywiad, chcąc niejako zrównoważyć pewne niemożliwe do przezwyciężenia ograniczenia, z jednej strony wykształcił wspomniany wcześniej mechanizm masowego zbierania informacji za pośrednictwem źródeł osobowych, z drugiej zaś zrobił niewiarygodny użytek z informatyzacji. Jak już wcześniej wspomniano, chiński potencjał ofensywny w cyberprzestrzeni (rozumianej jako „wszechogarniająca świat domena informacyjna" ${ }^{40}$ ) jest prawdopodobnie jednym $\mathrm{z}$ największych na świecie ${ }^{41}$. Wydaje się, iż wiodącym celem działalności cyberszpiegowskiej o chińskiej proweniencji jest pozyskanie zaawansowanych technologii wprost z wysoko rozwiniętych krajów Zachodu, głównie Stanów Zjednoczonych. Zdaniem Joe McReynoldsa w ChRL funkcjonują trzy grupy podmiotów odpowiedzialne za cyberataki za granicą, które wspólnie działają na rzecz państwa, realizując odgórne wytyczne: wyspecjalizowane oddziały wojskowe (jak chociażby niesławna jednostka 61398 z Szanghaju) ${ }^{42}$, cywile pracujący w instytucjach rządowych (głównie podległych Ministerstwu Bezpieczeństwa Państwowego) oraz zakontraktowani specjaliści zewnętrzni $^{43}$. Z drugiej strony analitycy korporacji FireEye w raporcie Red Line Drawn: China Recalculates Its Use of Cyber Espionage wykluczają

382016 Report to Congress..., op.cit., s. 294-295.

39 P. Orłowski, Chińscy szpiedzy nad Wisła: czego szukają?, http://konflikty.wp.pl/ kat,1023303,page,2,title,Chinscy-szpiedzy-nad-Wisla-czego-szukaja,wid,12247579, wiadomosc.html?ticaid=11a096\&_ticrsn=3 [dostęp: 1.09.2017]; A. Doval, op.cit., s. 15.

40 J. Dereń, A. Rabiak, NATO a aspekty bezpieczeństwa w cyberprzestrzeni, [w:] Cyberbezpieczeństwo jako podstawa bezpiecznego państwa i spoteczeństwa w XXI wieku, red. M. Górka, Warszawa 2014, s. 202.

41 P. Borkowski, op.cit., s. 52; zob. szerzej: W.T. Hagestad II, $21^{\text {st }}$ Century Chinese Cyberwarfare, Ely 2012, passim.

42 Jej istnieniu Pekin nieustannie zaprzecza, jednakże amerykańscy dziennikarze śledczy zebrali pokaźne dossier na jej temat; zob. D.E. Sanger, D. Barboza, N. Perlroth, China's Army Is Seen as Tied to Hacking Against U.S, http://www.nytimes.com/2013/02/19/technology/chinasarmy-is-seen-as-tied-to-hacking-against-us.html [dostęp: 5.10.2017].

43 M. Kumar, China Finally Admits It Has Army of Hackers, https://thehackernews. com/2015/03/china-cyber-army.html [dostęp: 5.10.2017]. 
tę swoistą teorię monolitu i wskazują, że za identyfikowane jako chińskie działania w cyberprzestrzeni odpowiedzialny jest cały wachlarz państwowych wojskowych i prywatnych podmiotów (zakontraktowanych wykonawców, przestępców czy nacjonalistów) operujących z terytorium tego kraju (choć nie zawsze i to jest pewne ${ }^{44}$ ), a już na pewno nierealizujących jednych wytycznych i jednego odgórnego planu. Rzeczony raport dotyczy przedziału czasowego obejmującego lata 2013-2016 i wymienia 262 cyberataki, za które odpowiedzialnością zostały obarczone 72 podmioty „zza Wielkiego Muru”. Przeszło 2/3 rozpoznanych przypadków dotyczyło instytucji i firm ulokowanych na terytorium Stanów Zjednoczonych, zaś 80 ataków aż 25 innych krajów (m.in.: Wielkiej Brytanii, Japonii, Kanady, Włoch, Szwajcarii, Niemiec) ${ }^{45}$. Powtarzające się chińskie ataki w cyberprzestrzeni były jednym z katalizatorów ogólnokrajowej debaty w USA na temat chińskiego braku poszanowania dla praw własności intelektualnej, która szczególnie uderza w amerykański sektor zaawansowanych technologii. Raport Amerykańskiej Komisji ds. Handlu Międzynarodowego z 2011 roku szacuje straty amerykańskich firm z tego tytułu w samym tylko 2009 roku na 48 miliardów dolarów ${ }^{46}$. Cztery lata później z Agencji Bezpieczeństwa Narodowego (NSA) wyciekły informacje wskazujące, że od 2010 roku Agencja wykryła ataki chińskich hakerów na blisko 700 podmiotów ulokowanych w USA. Ich celem była kradzież zaawansowanych technologii ${ }^{47}$. FireEye podkreśla, iż bez analizy zastosowania, trudno

44 A. Kozłowski, Chińczycy stoją za atakiem na Equifax? [KOMENTARZ], http://www. cyberdefence24.pl/674222, chinczycy-stoja-za-atakiem-na-equifax-komentarz [dostęp: 5.10.2017].

45 Redline Drawn: China Recalculates Its Use of Cyber Espionage, s. 12, https://www.fireeye.com/content/dam/fireeye-www/current-threats/pdfs/rpt-china-espionage.pdf [dostęp: 5.10.2017].

46 D. Palmer, S. Maler, China piracy cost U.S. firms \$48 billion in 2009: report: http://www. reuters.com/article/2011/05/18/us-usa-china-piracy-idUSTRE74H6CO20110518 [dostęp: 5.10.2017]; zob. więcej: D.T. Okun et al., China: Effects of Intellectual Property Infringement and Indigenous Innovation Policies on the U.S. Economy, Investigation No. 332-519, Waszyngton 2011, passim.

47 R. Windrem, Exclusive: Secret NSA map shows China cyber attacks on US target, https:// www.nbcnews.com/news/us-news/exclusive-secret-nsa-map-shows-china-cyber-attacks-ustargets-n401211 [dostęp: 05.10.2017]; A. Collman, Shocking map shows how Chinese hackers have breached American cyber-security more than 600 times to steal secrets in the past five years, http://www.dailymail.co.uk/news/article-3181179/Shocking-map-shows-600-times-Chinesehackers-stolen-American-secrets-past-five-years.htm [dostęp: 5.10.2017]. 
jednoznacznie określić, czy dana technologia została wykradziona z przeznaczeniem na cele militarne czy cywilne, co dodatkowo zaciemnia obraz chińskiej działalności cyberszpiegowskiej ${ }^{48}$.

Co dość oczywiste, chińskie władzy do niedawna całkowicie wypierały się jakichkolwiek związków z nielegalną działalnością w cyberprzestrzeni ${ }^{49}$. Wydaje się, że pod naciskiem Waszyngtonu Chiny postanowiły przyznać się do posiadania jednostek wojskowych przeznaczonych do prowadzenia cyberwojny ${ }^{50}$, a ponadto sygnować porozumienie o wzajemnym ograniczeniu ataków cybernetycznych ${ }^{51}$. Choć administracja prezydenta Baracka Obamy określała je jako spory sukces, to jednak cytowany powyżej raport FireEye jest w tej kwestii dość powściągliwy i wskazuje, że znaczący spadek liczby incydentów sieciowych miał miejsce już na rok przed zawarciem rzeczonego porozumienia. Summa summarum w ciągu 3 lat ich liczba jednak zmniejszyła się znacząco - z poziomu przekraczającego sześćdziesiąt ataków miesięcznie do raptem kilku ${ }^{52}$. Obiektywnie trudno nie uznać tego za sukces, jednakże w kontekście wspomnianej już wcześniej reformy sił zbrojnych wdrożonej przez przewodniczącego Xi Jingpinga pojawiła się interesująca interpretacja tego zjawiska. Zdaniem niektórych ekspertów w ramach jednego z filarów reformy, którym jest szeroko zakrojona kampania antykorupcyjna wymierzona w oficerów średniego i głównie wysokiego

48 Redline Drawn..., op.cit., s. 14

49 T. Stasiak, Xi: Chiny nie wspieraja cyber szpiegostwa, https://www.pb.pl/xi-chiny-nie-wspieraja-cyber-szpiegostwa-806578 [dostęp: 5.10.2017]; Cyberatak na media w USA. Chiny: to nie my, https://www.wprost.pl/swiat/386482/Cyberatak-na-media-w-USA-Chiny-to-nie-my.html [dostęp: 5.10.2017]; Chiny oburzone oskarżeniami nt. cyber-szpiegostwa, https://www. wprost.pl/swiat/157468/Chiny-oburzone-oskarzeniami-nt-cyber-szpiegostwa.html [dostęp: 5.10.2017].

50 M. Kumar, op.cit.; zob. szerzej na temat cyberwojny: M. Górka, Cyberataki jako nowy sposób prowadzenia wojny, [w:] Bezpieczeństwo w świecie przedstawionym a kultura bezpieczeństwa, red. N. Gburzyńska, J. Rak, Toruń 2015, s. 42-59; idem, Cyberwojna - bezgraniczne nie-bezpieczeństwo, [w:] Instytucje publiczne bezpieczeństwa, red. D. Sienkiewicz, M. Pogonowski, Koszalin 2015, s. 91-108.

51 Remarks by President Obama and President Xi of the People's Republic of China in Joint Press Conference, https://obamawhitehouse.archives.gov/the-press-office/2015/09/25/ remarks-president-obama-and-president-xi-peoples-republic-china-joint [dostęp: 5.10.2017]; FACT SHEET: President Xi Jinping's State Visit to the United States, https://obamawhitehouse. archives.gov/the-press-office/2015/09/25/fact-sheet-president-xi-jinpings-state-visit-unitedstates [dostęp: 5.10.2017].

52 Redline Drawn..., op.cit., s. 11. 
szczebla, przywódcy KPCh dążyli do ograniczenia wykorzystania wojskowego potencjału do cyberszpiegostwa na rzecz firm prywatnych w zamian za łapówki ${ }^{53}$. Na zakończenie wątku szpiegostwa w cybesprzestrzeni warto podkreślić, że choć natężenie chińskich ataków spada, to stopień ich wyrafinowania zdecydowanie rośnie, co dla służb innych krajów stanowić może spore wyzwanie ${ }^{54}$.

Jak już wspomniano wcześniej, chińska diaspora to niewątpliwy atut w rękach chińskiego wywiadu. Sprzyja temu z jednej strony więź z ojczyzną, jaką utrzymują Chińczycy przebywający na emigracji nawet od wielu pokolen ${ }^{55}$, ale przed wszystkim funkcjonujący w Chinach od tysięcy lat "system" guanxi. Na jego temat powstało na Zachodzie wiele opracowańn ${ }^{56}$, które próbują ten złożony koncept przełożyć na język zrozumiały dla Europejczyków czy Amerykanów. Istota problemu jak zwykle sprowadza się do głębokich różnic kulturowych, na których opisanie brak tu miejsca ${ }^{57}$. Należy pamiętać, iż Chińczycy nastawieni są zdecydowanie bardziej pro-relacyjnie niż np. my, Polacy, co znajduje właśnie swoje odbicie w guanxi. Termin ten odpowiada w pewnym stopniu temu, co w naszej części świata nazwalibyśmy koneksjami czy pozycją społeczną. Guanxi to jednak pojęcie zdecydowanie bardziej pojemne - te swoiście rozumiane „znajomości” decydowały i wciąż decydują w Chinach z jednej strony o karierze zawodowej lub biznesowej ${ }^{58}$, a z drugiej o zawarciu małżeństwa ${ }^{59}$. W kraju,w którym brak jest powszechnego systemu ubezpieczeń społecznych, odpowiednio rozbudowana siatka guanxi jest często jedynym ratunkiem w przypadku nagłej choroby czy niezdolności do pracy, gdyż pozwala szybko pożyczyć

53 Ibidem, s. 5-6; F.S. Gady, Are Chinese Cyberattacks against US Targets in Decline?, https://thediplomat.com/2016/06/are-chinese-cyberattacks-against-us-targets-in-decline/ [dostęp: 5.10.2017].

54 Ibidem; Redline Drawn..., op.cit., s. 15.

55 M. Jacoby, Chiny bez makijażu, Warszawa 2016, s. 68.

56 Zob. m.in. Y.H. Wong, T.K. Leung, Guanxi: Relationship Marketing in a Chinese Context, Nowy Jork-Londyn-Oxford 2001, passim; Y.L. So, A. Walker, Explaining Guanxi: The Chinese Business Network, Londyn-Nowy Jork 2006, passim; J. Guan, Guanxi: The Key to Achieving Success in China, „Sino-Platonic Papers” 2011, No. 217, s. 1-12. passim.

57 Zob. więcej: M. Jacoby, op.cit., passim; R.E. Nisbett, Geografia myślenia, Sopot 2015,

58 M. Jacoby, op.cit., s. 149-150; J.K. Fairbank, op.cit., s. 78.

59 M. Jacoby, op.cit., s. 174. 
niezbędne sumy od „znajomych”, z którymi utrzymuje się odpowiednie relacje $^{60}$. Guanxi jest w chińskim społeczeństwie narzędziem, a zarazem celem samym w sobie. Decyduje o powodzeniu w praktycznie każdej aktywności obejmującej sferę zawodową ${ }^{61}$ czy prywatną. Jednocześnie o rozszerzenie własnej „sieci” Chińczycy troszczą się przez całe życie i często przekazują ją własnym dzieciom. Kontakty nawiązuje się i pielęgnuje przez rekomendacje ze strony znajomych czy spotkania na gruncie towarzyskim, wszelakiego rodzaju przysługi, ale także dawanie i przyjmowanie drogich prezentów, wystawnych kolacji, wspomnianych wcześniej pożyczek czy przez protekcję w trakcie kariery zawodowej, naukowej lub w interesach. W uproszczeniu można stwierdzić, iż to, co w naszej części świata uznane zostałoby za zachowanie co najmniej wątpliwe moralnie lub nawet zabronione prawnie (drogie podarunki dla urzędników czy pożyczki bez oczekiwania ich spłaty), w Chinach jest zachowaniem uznawanym za pożądane i nawet konieczne dla dalszego wzmacniania guanxi.

Zdaniem autorów guanxi może stanowić o sile chińskich służb wywiadowczych działających w oparciu o chińską diasporę rozsianą po świecie. Chińczycy nie zwykli odmawiać prośbom osób będących w ich „sieci”, gdyż wiązałoby się to najczęściej z zerwaniem kontaktu nie tylko z osobą proszącą o „przysługę”, ale także szeregiem innych członków guanxi, którzy uznaliby ją za niewiarygodną. Jednocześnie zrealizowana prośba staje się swoistym „długiem”, na którego oddanie naciskać nie należy, choć gdy „wierzyciel” sam znajdzie się w potrzebie, to szansa, że „dłużnik” mu odmówi, jest z wyżej wymienionych powodów bardzo niewielka. Takie odpowiednio wykorzystane „przysługi”, obietnice wsparcia członków rodziny, którzy pozostali w Chinach, czy wizja przyjęcia do szczególnie atrakcyjnego grona towarzyskiego mogą stać się kuszącym wabikiem, który chińskie służby mogą wykorzystywać w celu zdobycia informacji za pośrednictwem Chińczyków przebywających na emigracji. Biznesmeni robiący interesy w ChRL mogą zostać „poproszeni” o zakup technologii szczególnie interesującej służby czy inne tego typu „usługi”. Spełnienie takowej prośby prawdopodobnie nie będzie dla nich kosztowne, z drugiej

\footnotetext{
60 Ibidem, s. 153-155.

61 Zob. J. Guan, op.cit., s. 3-8.
} 
strony odmowa może się skończyć zerwaniem lukratywnych kontaktów biznesowych. Siła guanxi polega z jednej strony na wzajemności, z drugiej zaś na niedomówieniach, których znaczenie jest oczywiste dla Chińczyków, a zarazem niezrozumiałe dla osób z zewnątrz.

\section{Podsumowanie}

Chińskie podejście do wywiadu wydaje się odpowiadać mocarstwowym ambicjom tego państwa. Z odmiennej kulturowo perspektywy trudno jednak określić i ująć w spójnych ramach jego specyfikę. Nie ułatwia tego również ograniczony zasób źródeł, do których należy zaliczyć głównie opracowania, a więc materiał mający charakter wtórny, co oznacza, że został on poddany już pewnej interpretacji. Obraz, który wyłania się jednak z badań nad chińskim wywiadem, to przede wszystkim szerokie, wręcz totalne pod względem wykorzystania sił i środków podejście do pozyskiwania informacji oraz interesująca specyfika pracy ze źródłami osobowymi.

W kontekście szeroko zakrojonego podejścia do zdobywania informacji pamiętać jednak należy, że wymaga to znacznych zasobów umożliwiających odpowiednią ich analizę. O ile Chiny dysponują ogromnym demograficznym potencjałem, o tyle przygotowanie odpowiednio wyspecjalizowanej kadry jest zadaniem trudnym, długotrwałym i kosztownym. Nie jest więc do końca jasne, jaki jest efekt działań tak szeroko zakrojonych, tj. czy z wielkiego zasobu pozyskanych informacji czyniony jest odpowiedni użytek. Trudno również zweryfikować, jakiego typu informacje są pozyskiwane przez pracowników instytucji niezwiązanych z Ministerstwem Bezpieczeństwa Państwowego czy strukturami wojskowymi. Wydaje się, że błędne byłoby założenie, że służba o tradycjach sięgających starożytności polegałaby jedynie na de facto wywiadzie jawnoźródłowym wspartym działalnością w cyberprzestrzeni (nawet prowadzoną z rozmachem). Charakteryzowanie chińskiego wywiadu jedynie przez ten pryzmat może wypaczać istotę rzeczy. Zasadne więc wydaje się analizowanie zadań poszczególnych instytucji przeznaczonych do pełnienia służby wywiadowczej, tak cywilnych, jak i wojskowych. Zaliczyć do nich należy przede wszystkim Ministerstwo Bezpieczeństwa Publicznego oraz dawne Departamenty II, III i IV Sztabu Generalnego ChALW. W artykule podano 
zarys ich zadań oraz struktur organizacyjnych, mając jednak świadomość, że informacje te są trudne do jednoznacznej weryfikacji. W zakresie metod pracy należy zwrócić uwagę przede wszystkim na koncept guanxi. Jest to kwestia zasługująca na pogłębione badania w zakresie potencjalnego zagrożenia dla bezpieczeństwa, a punktem wyjścia są właśnie rozważania nad specyfiką pracy wywiadu chińskiego.

\author{
mgr Marcin Adamczyk \\ Zakład Studiów nad Bezpieczeństwem \\ Instytut Studiów Międzynarodowych \\ Uniwersytet Wrocławski \\ ul. Koszarowa 3, 51-149 Wrocław \\ marcin.amadeusz.adamczyk@gmail.com \\ mgr Kamil Baraniuk \\ Zakład Studiów Regionalnych i Rozwojowych \\ Instytut Studiów Międzynarodowych \\ Uniwersytet Wrocławski \\ ul. Koszarowa 3, 51-149 Wrocław \\ kam.baraniuk@gmail.com
}

\title{
Bibliografia
}

2016 Report to Congress, US-China Economic and Security Review Commission, Waszyngton 2016.

Adamczyk M., Media we wspótczesnym państwie totalitarnym na przykładzie Chińskiej Republiki Ludowej, [w:] Media XXI wieku. Studia interdyscyplinarne, red. A. Momot, A. Drabina, Wrocław 2016.

Becker P., Eyes and ears of the dragon, http://www.nisa-intelligence.nl/ PDF-bestanden/NISAcongresBecker.pdf.

Borkowski P., Koncepcja cyberbezpieczeństwa w ujęciu Chińskiej republiki Ludowej - wybrane aspekty, „Przegląd Bezpieczeństwa Wewnętrznego" 2015, No. 13.

Brookes P., Legion of Amateurs: How China Spies, http://www.heritage. org/commentary/legion-amateurs-how-china-spies. 
Collman A., Shocking map shows how Chinese hackers have breached American cyber-security more than 600 times to steal secrets in the past five years, http://www.dailymail.co.uk/news/article-3181179/Shocking-map-shows-600-times-Chinese-hackers-stolen-American-secrets-past-five-years.htm.

Chen Wenqing, http://chinese-leaders.org/chen-wenqing/.

China reorients strategic military intelligence, http://www.janes.com/images/assets/484/68484/China_reorients_strategic_military_intelligence_edit.pdf.

China's intelligence services and espionage operations, US-China Economic and Security Review Commision, Waszyngton 2016.

Chiny oburzone oskarżeniami nt. cyber-szpiegostwa, https://www.wprost. $\mathrm{pl} /$ swiat/157468/Chiny-oburzone-oskarzeniami-nt-cyber-szpiegostwa.html.

Cyberatak na media w USA. Chiny: to nie my, https://www.wprost.pl/swiat/386482/Cyberatak-na-media-w-USA-Chiny-to-nie-my.html.

Decoding MSS: Ministry of State Security - China, http://www.asianwarrior.com/2016/09/decoding-mss-ministry-of-state-security-china. html.

Dereń J., Rabiak A., NATO a aspekty bezpieczeństwa w cyberprzestrzeni, [w:] Cyberbezpieczeństwo jako podstawa bezpiecznego państwa i społeczeństwa w XXI wieku, red. M. Górka, Warszawa 2014.

Dębicka D., Reformy Deng Xiaopinga i ich wpływ na gospodarkę współczesnych Chin, „Pisma Humanistyczne” 2013, nr 9.

Doval A., Chinese Intelligence: From a party outfit to cyber warriors, New Delhi 2013.

FACT SHEET: President Xi Jinping's State Visit to the United States, https://obamawhitehouse.archives.gov/the-press-office/2015/09/25/ fact-sheet-president-xi-jinpings-state-visit-united-states.

Fairbank J.K., Historia Chin. Nowe spojrzenie, Warszawa-Gdańsk 2004.

Feakin T., Enter the Cyber Dragon. Understanding Chinese intelligence agencies's cyber capabilities, „Special Report” 2013, No. 50.

Gady F.S., Are Chinese Cyberattacks against US Targets in Decline?, https://thediplomat.com/2016/06/are-chinese-cyberattacks-against-us-targets-in-decline/. 
Goodman D., Deng Xiaoping and the Chinese Revolution: A Political Biography, Londyn-Nowy Jork 1994.

Góralczyk B., Chiny piątej generacji, https://www.obserwatorfinansowy. $\mathrm{pl} /$ tematyka/makroekonomia/chiny-piatej-generacji/.

Górka M., Cyberataki jako nowy sposób prowadzenia wojny, [w:] Bezpieczeństwo w świecie przedstawionym a kultura bezpieczeństwa, red. N. Gburzyńska, J. Rak, Toruń 2015.

Górka M., Cyberwojna - bezgraniczne nie-bezpieczeństwo, [w:] Instytucje publiczne bezpieczeństwa, red. D. Sienkiewicz, M. Pogonowski, Koszalin 2015.

Guan J., Guanxi: The Key to Achieving Success in China, „Sino-Platonic Papers" 2011, nr 217.

Hagestad II W.T., 21st Century Chinese Cyberwarfare, Ely 2012.

Intelligence Services, Part. 1: Espionage with Chinese Characteristics, https://wikileaks.org/gifiles/attach/133/133464_INTEL_SERVICES_ CHINA.pdf.

Interview. T. Van Magers, http://www.pbs.org/wgbh/pages/frontline/ shows/spy/interviews/vanmagers.html.

Jacoby M., Chiny bez makijażu, Warszawa 2016.

Jakobson L., Knox D., New foreign policy actors in China, „SIPRI Policy Paper", 2016, No. 26.

Kamil M., Nieważne, jakiego koloru jest kot - ważne, by tapat myszy. Deng Xiaoping i droga komunistycznych Chin do kapitalizmu, „Ogrody Nauk i Sztuk" 2015, nr 5.

Kozłowski A., Chińczycy stojq za atakiem na Equifax? [KOMENTARZ], http://www.cyberdefence24.pl/674222,chinczycy-stoja-za-atakiem-na-equifax-komentarz.

Kumar M., China Finally Admits It Has Army of Hackers, https://thehackernews.com/2015/03/china-cyber-army.html.

Książczak A., Chińskie stużby specjalne XXI wieku - organizacja, metody i formy dziatania, „Forum” 2015, nr 2.

Madejczyk P., Rok 1956: Chiny a polski Październik, https://www.swps.pl/ nauka-i-badania/materialy-ccaw/2444-rok-1956-chiny-a-polski-pazdziernik. 
Mattis P., Assessing the Foreign Policy Infuence of the Ministry of State Security, „China Brief” 2011, No. 11.

Mattis P., Chen Wenqing: China's New Man for State Security, http://nationalinterest.org/feature/chen-wenqing-china's-new-man-state-security-14153.

Mattis P., Military Intelligence at a Crossroads, https://www.thecipherbrief.com/military-intelligence-at-a-crossroads.

Mattis P., The Analytic Challenge of Understanding Chinese Intelligence Services, „Studies in Intelligence” 2012, No. 3 (56).

Mattis P., Kania E., Modernizing Military Intelligence: Playing Catchup (Part Two), https://jamestown.org/program/modernizing-military-intelligence-playing-catchup-part-two/.

Monk P., Chinese Spies and Our National Interest, http://quadrant.org.au/ magazine/2012/06/chinese-espionage-and-australia-s-national-interest/. MSS Organization, https://fas.org/irp/world/china/mss/org.htm.

Nisbett R.E., Geografia myślenia, Sopot 2015.

Okun D.T. et al., China: Effects of Intellectual Property Infringement and Indigenous Innovation Policies on the U.S. Economy, Investigation No. 332-519, Waszyngton 2011.

Orłowski P., Chińscy szpiedzy nad Wisła: czego szukaja?, http://konflikty. wp.pl/kat,1023303,page,2,title,Chinscy-szpiedzy-nad-Wisla-czego-szukaja,wid,12247579, wiadomosc.html?ticaid=11a096\&_ticrsn=3.

Palmer D., Maler S., China piracy cost U.S. firms \$48 billion in 2009: report: http://www.reuters.com/article/2011/05/18/us-usa-china-piracy-idUSTRE74H6CO20110518.

Pożaroszczyk D., Wywiad Chińskiej Republiki Ludowej - Charakterystyka i zagrożenia dla Polski, „Przegląd Bezpieczeństwa Wewnętrznego” 2017, nr 16.

Redline Drawn: China Recalculates Its Use of Cyber Espionage, https:// www.fireeye.com/content/dam/fireeye-www/current-threats/pdfs/ rpt-china-espionage.pdf.

Remarks by President Obama and President Xi of the People's Republic of China in Joint Press Conference, https://obamawhitehouse.archives. gov/the-press-office/2015/09/25/remarks-president-obama-and-president-xi-peoples-republic-china-joint. 
Sanger D.E., Barboza D., Perlroth N., China's Army Is Seen as Tied to Hacking Against U.S, http://www.nytimes.com/2013/02/19/technology/ chinas-army-is-seen-as-tied-to-hacking-against-us.html.

So Y.L., Walker A., Explaining Guanxi: The Chinese Business Network, Londyn-Nowy Jork 2006.

Stasiak T., Xi: Chiny nie wspieraja cyber szpiegostwa, https://www.pb.pl/ xi-chiny-nie-wspieraja-cyber-szpiegostwa-806578.

Stober D., China is Different, http://www.pbs.org/wgbh/pages/frontline/ shows/spy/spies/different.html.

Stokes M.A., Lin J., Russel Hsiao L.C., The Chinese People's Liberation Army Signals Intelligence and Cyber Reconnaissance Infrastructure, https://project2049.net/documents/pla_third_department_sigint_cyber_stokes_lin_hsiao.pdf.

Swaine M.D., The role of Chinese military in national security policymaking. Revised edition, Rand National Defence Research Institute, Waszyngton 1998.

Windrem R., Exclusive: Secret NSA map shows China cyber attacks on US target, https://www.nbcnews.com/news/us-news/exclusive-secret-nsa-map-shows-china-cyber-attacks-us-targets-n401211.

Wong Y.H., Leung T.K., Guanxi: Relationship Marketing in a Chinese Context, Nowy Jork-Londyn-Oxford 2001.

Żmuda M., Przyczyny wejścia Chińskiej Republiki Ludowej na ścieżke przyspieszonego wzrostu gospodarczego, [w:] Wybrane problemy gospodarki światowej pierwszej dekady nowego wieku, red. W. Michalczyk, Wrocław 2009.

\title{
The intelligence service of People's Republic of China - an outline of structures and methods of activity
}

\begin{abstract}
Studying Chinese intelligence service brings researchers and their readers together to identify the specific ways in which the state achieves its goals internationally. Intelligence is deeply rooted in the Chinese understanding of interstate competition, and its essential effect, ie knowledge, is a key element in rational decision-making in foreign and security policy. Intelligence is also an important
\end{abstract}


tool for reducing the technological gap between the PRC and Western countries. Years of tradition, size and international status make the intelligence service of the People's Republic of China have certain characteristics that characterize its operation. Their description may help to understand the philosophy underlying the intelligence work on Chinese characteristics, the role of these institutions in foreign policy and their methodology of action. Authors decided to focus on two aspects: the structures responsible for the interview and the specificity of the approach to collecting information. The main reason for adopting such a perspective is the desire to outline the main differences in Chinese intelligence work in relation to Western countries of cultural or even Russian. A look at the structure of the intelligence and its place in the system brings us closer to understanding what role the Chinese attribute and what they expect from the institutions called to collect information.

Keywords: China, organizational structure of the intelligence service, cyber spying, guanxi

\section{Интемектуальные службы Китайской Народной Республики - схема структур и методов работы}

\section{Абстракт}

Изучение китайских разведывательных служб объединяет исследователей и их читателей, чтобы понять специфику того, как государство Аостигает своих целей на межАународном уровне. Интемлект глубоко укоренен в китайском понимании межгосударственной конкуренции, и его существенный эффект, то есть знания, явАяется кцючевым элементом рационального принятия решений в области внешней политики и политики безопасности. Интелмект также является важным инструментом Аля сокращения технологического разрыва межАу КНР и Западом. Годы традиций, размеров и межАународного статуса Аелают разведывательные службы Китайской Народной Республики определенными характеристиками, характеризующими ее деятельность. Их описание может помочь понять философию, лежащую в основе разведывательной работы по китайским особенностям, роль этих институтов во внешней политике и их методологию Аействий. Авторы решили сосредоточиться на Авух аспектах: структурах, ответственных за интервью, и специфике подхода к сбору информации. Основной причиной принятия такой перспективы явАяется стремление наметить основ- 
ные разАичия в работе китайской развеАки в отношении западных стран кумьтурного ими Ааже русского языка. ВзгляА на структуру интемлекта и его место в системе приближает нас к пониманию роли, которую китайцы приписывают и чего они ожиАают от институтов, призванных собирать информацию.

кмючевые слова: Китай, организационная структура разведывательной службы, кибер-шпионаж, гуаньси 